\title{
Sovjets barnbarn - rysserna i Baltikum
}

Kalle Kniivilä

Falun: Atlas 2016

320 sider. ISBN 9789173895101

Omtalt av: Sigbjørn Litland [MA, første ambassadesekretær ved Den Kgl. norske ambassade i Kyiv, sigbjorn.litland@mfa.no]

For 25 år siden rev de baltiske statene Estland, Latvia og Litauen seg løs fra Sovjetunionen etter 50 år under okkupasjon. De fleste feiret den nyvunne friheten, men for en stor del av befolkningen brakte den med seg en betydelig bakrus utover 1990-tallet. Brorparten av disse var migranter som hadde kommet til Baltikum som en del av den store industrialiseringen etter krigen, og som kanskje mer enn noen andre representerte det nye sovjetmennesket.

Disse befant seg nå innenfor grensene av land hvor de nasjonale fortellingene beskrev dem som representanter for okkupasjonsmakten, ikke som en del av det statsbærende og -byggende fellesskapet. Mye vann har rent i elven siden den gang, og i Vesten er disse strandede «russerne» - Sovjets barnebarn - nesten glemt.

For til tross for at de store spørsmålene om språk og statsborgerskap fortsatt er såre punkter uten en fullgod løsning, og at det er noe vanskeligere å komme seg opp og fram med et russisk navn, så er de fleste godt integrert i sine hjemland. Merkelappene «russere» og det mer nøytrale «russiskspråklige» er også problematiske, da de antyder ensartethet, og et egentlig hjem i Russland. I virkeligheten er de representanter for et utall folkegrupper som i mange tilfeller kun har det til felles at deres lingua franca var, og delvis er, russisk og at de selv eller forfedrene flyttet til de baltiske sovjetrepublikkene.

Det vil si, $i$ utgangspunktet er det alt de har til felles. I Ukraina sies det at Putin bidro til å skape den ukrainske nasjonen, $\mathrm{i}$ den forstand at de ble sveiset sammen gjennom annekteringen av Krim og konflikten i Donbass. På samme måte kan man hevde at de baltiske russerne er en politisk konstruksjon: De har nemlig også vært gjenstand for en betydelig og polariserende oppmerksomhet fra (hovedsakelig) nasjonalt innstilte politikere i både Baltikum og Russland. De førstnevnte har vært opptatt av å bevare sine små og utsatte nasjoner og språk fra trusselen fra øst, og det som har blitt sett som dens stedlige representanter. Sistnevnte har vært opptatt av å forsvare sine landsmenn i utlendighet, aller helst på en måte som gjør at Russland oppnår innflytelse eller kontroll i nabolandene $i$ vest.

Dessverre kommer vi i Vesten vanligvis først på at disse russerne eksisterer når forholdet mellom Russland og oss er nedadgående, som etter annekteringen av Krim og den Russlands-initierte og -styrte konflikten i Øst-Ukraina. Da husker vi dem 
også oftest som en potensiell femte-kolonne, en trussel mot de baltiske statene dersom bare Kreml velger å bruke dem slik.

Det er i denne kryssilden av ulike forventninger, krav og fordommer at Sovjets barnebarn har befunnet seg over 25 år. Og det er nettopp disse menneskene Kalle Kniivilä forsøker å komme inn under huden på, i sin tredje og foreløpig siste bok om nyere russisk politikk, sett gjennom vanlige menneskers øyne.

Boken som med sine korte men velformulerte setninger fyller 320 små og lettleste sider, tar form av en reiseskildring, basert på Kniivilas reiser gjennom de tre landene i løpet av sommeren 2015. Og mens hundrevis av mennesker på denne tiden mistet livet $\mathrm{i}$ en krig som den russiske propagandaen beskriver som motstand mot ukrainske nasjonalister på utrydningstokt, har Kniivila her laget et kraftfullt, men likevel mildt kampskrift mot forenklingen. Det er ikke et akademisk verk, men med en tematikk som denne er det like gjerne en styrke. Jeg har lest akademisk litteratur på området, hvor man av og til kan lure på om forfatterne selv har forstått hva de har skrevet. For både den allmenne og den spesielt interesserte leser som ønsker et oppdatert, lettlest og framfor alt menneskelig og forståelig verk, vil jeg derfor anbefale denne boken på det varmeste. For skandinaviskspråklige som er interessert $\mathrm{i}$ temaet bør denne være førstevalget.

Bokens hovedtema er altså russerne i Baltikum og hvordan de med sine egne ord sier de har taklet livet og de skiftende omstendighetene, både før og etter at Sovjet forsvant. Vi møter mennesker i mange situasjoner og med høyst forskjellige historier og meninger: Fra grensevakten som i bokens første kapittel kikker over elven mot Narvas russiske søsterby Ivangorod, til nasjonalbolsjeviken som i flere tiår har agitert for at Krim er en del av Russland og er glad for at Putin endelig har forstått det; fra aktivisten som kjemper for de russiskspråkliges rettigheter, samtidig som hun hevder at ukrainerne ikke eksisterer som et eget folk, til klubbeieren i et russiskdominert område som nekter sine ansatte å svare på russisk, og mange, mange flere.

Noen har aldri vært i Russland, og har heller ikke noe ønske om det, mens andre som har vært der sier at de føler seg som fremmede. Språket er annerledes, mentaliteten er annerledes. Noen har et nostalgisk forhold til Russland som ide, eller Sovjetunionen, men kunne for sitt bare liv ikke tenke seg å flytte dit. Andre har tvert om selv flyttet andre veien etter Sovjets fall.

Kniiviläs bok er ingen blåøyd skildring hvor de russiske intervjuobjektene er utelukkende positivt skildret, mens majoritetsbefolkningen - som i det store og hele ikke selv intervjues - fremstilles som undertrykkere eller store slavedrivere. Overraskende nok har russerne ofte betydelig sympati og forståelse for at balterne valgte å handle som de gjorde etter Sovjetunionens fall, selv om de har vanskeligheter med å forsone seg med språklovene og statsborgerskapslovene som vanskeliggjør deres egen hverdag.

Kniivilä fornekter ikke de tidvis store meningsforskjellene mellom russerne og majoritetsbefolkningen. Heller ikke at enkelte har mildt sagt tvilsomme holdninger, og at det nok finnes de som kunne tenke seg å agere etter slike overbevisninger om sjansen bød seg. Men dette gjelder langt i fra alle, som et av intervjuobjektene sier: «Det jobbiga är att alla ryssar klumpas ihop [.. .] Till och med den liberala delen [...] 


\section{2 | SIGBJØRN LITLAND}

har någon sorts orientalistisk innställning gentemot den ryskspråkiga minoriteten. Den ses som en enhetlig massa som alltid är som den är» (s. 168).

Framfor alt er det tvert imot mangfoldet av stemmer som preger dem, og det er lite som tyder på at Sovjets barnebarn en masse ville valgt Russlands side i tilfelle Kreml skulle forsøke seg på et ukrainsk scenario i Baltikum. For som nasjonalbolsjeviken Lindeman sier: «Baltikum har redan flugit ur boet». 